\title{
Historical insight on provincial merchants of the late 19th century
}

\author{
Azat Mukhametshin ${ }^{1 *}$, Svetlana Grakhova ${ }^{1}$, Irina Zakharova ${ }^{1}$, Nina Belyaeva ${ }^{1}$, and Karina \\ Okisheva $^{1}$ \\ ${ }^{1}$ Naberezhnye Chelny State Pedagogical University, 28, Nizametdinov str., 423806, Naberezhnye \\ Chelny, Russia
}

\begin{abstract}
The authors of the article believe that it is important to study the deep essence of the writer's works in order to understand the period of time that he depicts. D.I. Stakheyev contributed to the development of the genres of sketch and short story as he discussed new subjects and ideas through studying the life of the Russian province. In addition, the value of his works is that they touch upon a wide range of universal problems that are of great importance in our time. The article gives a broader idea of "small" forms of literary works in Russia in the mid- $19^{\text {th }}$ century. The interpretation of the images of the provincial merchants created by Stakheyev, the Russian writer of the second half of the 19 century, is of scientific interest to us. To understand the nature of provincial merchants Stakheyev goes his own way: he shows the essence of the merchant class through the problems of fathers and children, of crime and punishment, and of the "golden calf" influence on everyday life. The provincial town, marketplace, forest trade are elements depicting a long-established patriarchal world that is far from civilization and not affected by European style of life. The article was written to be used in the educational process. Studying the works of D.I. Stakheev within the framework of additional education, teachers and students of a modern school can discover pages of Russian literature, that were unknown for them, realize the moral problems that were faced by the previous generations.
\end{abstract}

\section{Introduction}

In the $60-70$ s of the 19th century a generation of prose writers in Russian literature followed the traditions of the natural school. They strived not only to make sketches, but also to artistically study those aspects of reality that they observed, that seemed to be an expression of the general laws of life. This trend can be considered to be the leading one in the development of Russian literature in the second half of the $19^{\text {th }}$ century. It was the trend that determined the main direction of the creative activity of the young writers who started their literary activity at that time (N.G. Pomyalovsky, F.M. Reshetnikov, V.A. Sleptsov, A.I. Levitov, N. Uspensky, and many others). They came to literature with their own themes, ideas, genres, and creative principles. Most of them were from simple families. They were well aware of the life of different classes, which was depicted in their works. In their own

\footnotetext{
* Corresponding author: ngpu.nis@gmail.com
} 
way, they filled a gap in the literature of "big" writers, such as Dostoevsky and Tolstoy, who were passionate about creating large-scale synthesizing forms. In particular, the Russian heartland and its most colorful and active representatives - the merchants - were of little interest to them $[1,2]$.

\section{Materials and methods}

Our scientific interest is concentrated on the interpretation of images of provincial merchants depicted by the Russian writer of the late 19th century D.I. Stakheyev.

The methodological basis of the study is an orientation to the traditional historical and cultural approach to literature. We apply a comparative-typological (or structuraltypological) method in our study. Its objective is to determine various kinds of relations between literary works. In addition, our investigation demonstrates principles of a systematic and holistic analysis of literary and artistic works.

The theoretical basis is comprised of the works written by P.V. Bykov [3], N.M. Valeyev [4], [5], S.F. Krivshenko [6], V.F. Kudryavtsev [7], A. Attman [8], H.H. Kaplan [9], etc.

\section{Results and discussion}

Dmitriy Ivanovich Stakheyev was an author who depicted the Russian provincial life with its everyday concerns, rich folk culture, strong national character, and solid national foundations. He was one of the pioneers who provided the foundations for the new forms that more broadly represented the world around them. In his early works D.I. Stakheyev did not strive to produce large-scale creations. Although most of his works were sketches and short stories, they were artistically completed (Table 1).

Table 1. D.I. Stakheyev's Early Works Genres.

\begin{tabular}{|c|l|}
\hline Genres & \multicolumn{1}{|c|}{ Genre Description } \\
\hline $\begin{array}{c}\text { Short } \\
\text { Story }\end{array}$ & $\begin{array}{l}\text { 1) a small-sized narrative work of fiction; } \\
\text { 2) a verbal description of events [10]. }\end{array}$ \\
\hline Sketch & $\begin{array}{l}\text { Epic genre of prose with a clearly expressed } \\
\text { organizing role of the author; it is on the } \\
\text { borderline between fiction and social and } \\
\text { political journalism [10]. }\end{array}$ \\
\hline
\end{tabular}

In the $60-70$ s of the $19^{\text {th }}$ century the sketch story - a prose documentary genre, a brief sketch of life again became extremely popular. The comments related to characterizing the characters, the landscape, and various autobiographical things transformed the dialogized scene into a kind of story. Most of D.I. Stakheyev's early works were sketches (everyday, problematic, travelling, and ethnographic) and short stories. The sketch reached its higher level of genuine artistry as it was not only a documentary genre: it was multi-faceted, internally mobile, and full of various everyday details.

D.I. Stakheyev's first book "As a keepsake to many: Stories about the life in Russia, Siberia and on the Amur River" (1867) was devoted to the depiction of the life of the merchant class, which was different from the traditional idea. That tradition was established by N.A. Dobrolyubov [11], who depicted the merchants' way of life as the life with outdated relations, as a dying world. 
"The Fugitives" ("Begletsy i Beglyanki") depicts a typical tragedy of the "dark kingdom": a merchant-father wants to improve his finances and to marry his daughter to a widowermillionaire of fifty. Dunyasha decides to take a risky step and runs away with her beloved to get married secretly in church. However, it does not happen as on the way to the church they are overtaken by the people sent by her father.

Table 2. D.I. Stakheyev's Collections of Sketches and Short Stories (1860s-early 1870s).

\begin{tabular}{|c|l|}
\hline № & \multicolumn{1}{|c|}{ Title of the collection } \\
\hline 1 & $\begin{array}{l}\text { As a keepsake to many: Stories about Life in Russia, Siberia and } \\
\text { on the Amur River. - St. Petersburg: The author's edition, 1867. } \\
-303 p .\end{array}$ \\
\hline 2 & $\begin{array}{l}\text { Remote Places. - St. Petersburg: A.I. Shcherbakov, 1868. - 326p. } \\
\text { Beyond the Baikal Lake and on the Amur River: Travel }\end{array}$ \\
\hline 4 & $\begin{array}{l}\text { From China to Moscow. The Story of the Tea Box: Sketches. - }- \text { St. Petersburg: [Printing House of K. Wulff], 1869. } \\
\text { St. Persburg; Moscow: The Partnership of M.O. Wolf, 1870. - }\end{array}$ \\
\hline
\end{tabular}

The protest expressed by Dunyasha is not typical of Russian life at that time. According to D.I. Stakheyev, the heroine's challenge shows her strong character, self-consciousness of a new generation of merchants. At the same time, the author argues that there is a "spark of divine fire" both in young representatives of the merchant class, and in old people who are able to change their views on the patriarchal foundations of life [12].

Dunyasha of D.I. Stakheyev and Katerina Kabanova from "The Thunderstorm" ("Groza") by A.N. Ostrovsky are alike in many ways. They are "rays of light" illuminating the doomed "dark kingdom", testifying to the complete condemn of this class in Ostrovsky's drama while Stakheyev regards them as the characters purifying and reviving a strong powerful class.

Love experienced by the young women is regulated by their social class environment with its inviolable style of life that is important for its ideologists.

Literature could not remain "deaf" to the conceptual challenges of objective reality. And Russian sketch writers were the first to depict the process of capitalization. While the writers of the first half of the XIX century (Pushkin, Gogol) often showed how Russian life was influenced by money using allegory ("The Queen of Spades" ("Pikovaya Dama"), "Dead Souls" ("Myortvye Dushi")), the writers of the new time openly wrote about the "golden devil", often referring to the merchant environment. As the legalization of capital developed, the "tyrant" principles of the merchant world disappeared, the patriarchal despotism collapsed, there appeared new forms of human relations - often even more "predatory", which were depicted in the works of Saltykov-Shchedrin, Nekrasov, and Ostrovsky.

After the reforms of 1861 the "golden calf" became the "master" of life, which perverted the human soul and made it ugly and callous. The story "Benevolence" ("Blagopriobreteniye", 1868, collection "As a keepsake to many: ...") written by Stakheyev shows how the main character, Fyodor Grigoryevich Belov, is possessed by the thirst for enrichment. He even kills his son to achieve material well-being and join the merchant class. 
Fyodor Grigoryevich Belov collects money from the sale of vodka in villages. One day, having collected fifteen thousand rubles, he returns home, to the village of Chelnykovo. On the way home he thinks over a crime. Pretending to be ill, Belov sends his excited wife to the town office to bring a confidant with her as Belov is going to give him the collected money. Then the hero buries the money in the garden and sets fire to his own house, where there is his two-year-old son, who becomes a sacrifice to the "golden devil". The world of suffering people - in this case, the mother and her son - faces a wild man who strives to achieve his dream of wealth in any way, and they become his victims.

The evidence against Belov was not found, because he "could neither save the money, nor save his own son; he saved his life because the bed on which he slept was by the window" [13].

Having become rich in an unjust way, Belov turns greedy, cruel, and heartless; he is a tyrant and an exploiter. "The merchant Fyodor Grigoryevich Belov is rich and famous in the town of Cheremisov. His two-story stone house, like a palace, is opposite the blue cathedral church; through the Bohemian glass windows one can see all sorts of plants. His shops and barns are full of goods, and thousands of bags of bread, oats, barley, and peas are loaded from the barns into the horse-breeding machines; everything is personal property of Fyodor Grigoryevich" [13].

Belov changes in appearance. The author creates a social portrait of the new merchant, "he is no longer black-haired, clever and handsome guy with a small beard, time has changed him. He is hunched and grey-haired with a long white beard. His voice has become low - as if coming from a barrel, his eyes are always looking from under his thick brows, and he is always frowning [9]. This portrait speaks of the great artistic skill of young Stakheyev. The portrait is created on the contraposition of the past and the present with the typical details of the merchant's appearance - "a long white beard", "a low voice", and "the eyes from under his thick brows". At the same time, there is inner anxiety in the hero's portrait: "he is always frowning". He does not notice the charms of the world; he is only concerned about his useless wealth.

Fyodor Grigoryevich is a talented and hard-working man. But the committed crime results in a tragic breakdown. The tragedy has grown into him, and the fate pays Belov back for what he has done and often "he has really bad dreams ..., there is again the death cry of little Grisha in his ears" [10]. The merchant is overtaken by retribution, "Fyodor Grigoryevich was left all alone in his big house"; his second son is a miserable idler and a drunkard. The story ends with depicting old age life. He "is still waiting for his death hour, but it is not approaching. Fyodor Grigoryevich has lost his sight and got old, but he is still living and living. He has won fame and respect of his fellow citizens. Waiting for his death hour he gets older, but time of the seventy-year-old man, an honorary citizen and a cavalier is not drawing near" [13].

Belov engages in charitable activity to atone the terrible sin of his youth, but "sometimes at night the old man anxiously tosses and turns in his warm bed." The merchant's soul suffers from the sin committed, his human nature revolts, and it is impossible for him to get rid of the suffering.

Even in his first works Stakheyev goes his own way: he does not copy the image of a merchant depicted by Ostrovsky, which is in the tradition of Russian literature. Belov cannot be regarded as a representative of the "dark kingdom". There is no ironic connotation in the title of the story. The writer aims to show the complex human character: the conscious and the unconscious, the desire to atone sins by doing "noble deeds".

In the preface to the collection "As a keepsake to many: ..." the author wrote, "I must say that the phenomena described in this book are not typical of the whole Russian merchant class, but, unfortunately, they are not exceptional - they exist and they will exist in the dark 
corners of Russia until the intellectual abilities of the merchants develop, until their education is measured by the information available in their district town" [13].

"Timber Merchants" ("Lesopromyshlenniki") depicts a terrible picture of nature destruction to make money. Money also makes it possible to buy people and destroy them. Money is not only good. An avaricious person has to overcome temptation that destroys morality. That is why people go to extremes to raise their capital, without thinking about the consequences: they kill their own children ("Benevolence"), carry on intrigues, humiliating a person in every possible way ("Timber Merchants"), sell their own daughters ("Fugitives"), lose their human face ("Carriage", "Do not Control my Temper" and many others). Stakheyev was well aware that a new master had appeared in human life, it was the "golden calf". True, the writer did not make generalizations or draw conclusions, like Gleb Uspensky, for example.

In his late works (dramas, novels), D.I. Stakheyev does not give categorical opinion, does not follow the traditional scheme of depicting the "wild" merchants with their bad upbringing and education. Sharing the point of view that there is a "sacred spark of divine fire" in every individual, which can flare up to show a strong and great human nature, the writer tries to see the "inner human" in the tyrant-merchant.

Thus, Stakheyev's view about the merchant class is complex. When depicting the negative images in his works, he tries to show both the immoral qualities and the virtues in the characters. It is no coincidence that the theme of the family appears in Stakheev's works. It becomes one of the leading leitmotifs in his sketches, short stories, plays, and novels.

The sketch story "District Town" ("Uezdny Gorod") describes "poor mental abilities" of the merchant environment, the attitude of the representatives of the "dark kingdom" to education, to the family. In the merchant community, women get their education from the Book of Hours, "The beautiful part of the district town grows up in their little rooms; thanks to visits of old nuns they learn to read and write. The penmanship, which is a completely useless thing in the household, is not taught at all [14]". Men "bear their heavy crosses of oppressive, overwhelming slavery, due to the fear but not for the sake of love" [3], "... after the death of his father the nephew of the rich Butakovs, has been staying for ten years at home without any money. I can imagine what might have happened to this "iron" man, if he had a small chance for success. When a child he was beaten by his father, now his uncles humiliate and insult him a lot; so he has become a drunkard. There is poverty, complete bitterness towards the whole world and a lonely life without any moral support" [14].

The fathers "feed" their children on the morals and instructions that they themselves do not understand. They do not think over the content of the "holy books", reading them only "for the process of reading", without thinking about the future. "They have never had any ideas of human responsibilities, of the common good, of their imperfect social life, and of the ways to improve it [14]". They strive to be wealthy; and what is wealth and why they strive for it using all sorts of bad and good ways - "these questions have never been raised by both the fathers and their children [14]".

In 1876 F.M. Dostoevsky in the "Writer's Diary" ("Dnevnik Pisatelya") divided the "merchant clan" into two categories: those who "continued to wear beards" and those who "started to wear tailcoats and to shave chins". The writer pointed out that the rich "with beards" were better than the "well-groomed chins". And he argued that the majority of rich people, who were not corrupted by wealth, were like images created by Ostrovsky. Perhaps, they were not much worse than those heroes, and most of them had much in common with ordinary people.

Taking into account all the shortcomings of the described class, Stakheyev depicts the "numerous merchants" with their best human qualities: purity, spirituality, and love for God. He himself was a deeply religious man, liked to talk about religion, and willingly discussed that subject. It was a matter of honor for true and self-respecting merchants, who saved every 
penny, to donate money to the church. Sometimes, they acted in a stupid and naïve way, like the hero from the story "Carriage" ("Izvoz"), or they donated large sums to the needs of the town like Yegor Yegorovich from the play "All Familiar Faces" ("Znakomye Vse Litsa"). Stakheyev also tells about other merchants, who give money for public needs. In "Public Figures" ("Obshchestvennye Deyateli") the author shows how they are lost, trying to understand why it is necessary to build a railroad [15]. The merchants come to dinner, sigh, groan, and become inspired by the "eloquent orator". As a result, "some of silent but intelligent citizens ... become desperate talkers and stupid people. Now it is not surprising to see such a merchant who suddenly, during the dinner ... starts talking about progress with his wife!"

\section{Conclusions}

Thus, we come to the following conclusions. The writer's works describe the vices of the merchant class: bad upbringing and education, lack of spiritual values, and avarice. However, they are mostly depicted in the works of the late 60 s of the $19^{\text {th }}$ century. These works speak of Stakheyev as a critical "witness" to the life of merchants. A reader has no doubts about the authenticity of the depicted images, phenomena of everyday life, and traditions. At the same time D.I. Stakheyev believed that Russian criticism, and a number of writers, failed to recognize the soul of the merchant-tyrant with "divine spark, which some day might break out to show all the power and greatness of human nature" [6].

The article was written in accordance with the state assignment of the Russian Federation Ministry of Education «Scientific and methodological support for the development of competencies of teachers in rural schools within the framework of the implementation of additional education for students programs " (applied research, 2021).

\section{References}

1. S.I. Grakhova, A.R. Gapsalamov, Bylye Gody. Russian historical journal 33(3), 410 416 (2014)

2. S. I. Grakhova, T.A. Magsumov, Bylye Gody. Russian historical journal 56(2), 871-877 (2020)

3. P.V. Bykov, Dmitry Ivanovich Stakheyev: A Critical Etude, D.I. Stakheyev Collection of works, vol. 1, 15-30 (The Partnership of M.O. Wolf, Moscow, 1902)

4. N.M. Valeyev, Dmitry Stakheyev. Creative Path of the Writer (Academy of Sciences of Tatarstan, Kazan, 1995)

5. N.M. Valeyev, I.V. Kornilova, Local Historians of Yelabuga (YSPU Publishing House, Yelabuga, 2007)

6. S.F. Krivshenko, The Coast of the Fatherland: The Romance of Heroism in the Literature about the Far East, 146 (Sovremennik, Moscow, 1988)

7. V.F. Kudryavtsev, Antiquity, Monuments, and Legends of the Kama Region, 191 (Gubernskaya Tipografiya, Vyatka, 1898)

8. A. Attman, The Scandinavian Economic History Review 19(3), 177-202 (1981)

9. H.H. Kaplan, Russia's Impact on the Industrial Revolution in Great Britain during the Second Half of the Eighteenth Century: The Significance of International Commerce (Forschungen zur Osteuropäischen Geschichte, Berlin, 1981)

10. I.P. Karpov, Dictionary of Critical Terms (Mari State University, Yoshkar-Ola, 2012) 
11. N.A. Dobrolyubov, Collection of works (Khudozhestvennaya literatura, Moscow; Leningrad, 1862)

12. S.F. Librovich, At the Book Post: Memoirs. Notes. Documents (Partnership of M.O. Wolf, Petrograd; Moscow, 1916)

13. D.I. Stakheyev, In Memory of Most: Stories about Life in Russia, Siberia and on the Amur River (Printing House of Ryumin and Co., St. Petersburg, 1867)

14. D.I. Stakheyev, Do not Break your Spirit: Selected Works (Tatknigoizdat, Kazan, 1992)

15. D.I. Stakheyev, Remote Places, 239-243 (A.I. Shcherbakov, St. Petersburg, 1868) 